\title{
The Research of Beach Deformation after Construction of the Jetties ${ }^{\dagger}$
}

\author{
Sang Kil Park ${ }^{1 *}$, Chong Soo Han ${ }^{1}$, Tae Young Roh ${ }^{1}$, O Young Park ${ }^{1}$, Ik Seong Ahn ${ }^{1}$ \\ and Ji Hun Lee ${ }^{1}$
}

${ }^{1}$ School of Civil \& Environmental Engineering Dept. of Civil Engineering, Pusan National University, Busan, Korea

(Manuscript Received September 3, 2011; Revised October 8, 2011; Accepted November 21, 2011)

\begin{abstract}
This research was described the prevention of coastal topographical change and sediment diffusive concentration incoming from small estuary after construction jetties. This structure is constructed to decrease sediment deposition incoming from the upstream river due to the urbanization and industrial development and to minimize effects on the coastal ecosystem. The physical modeling and numerical modeling for waves were conducted to analyze the configuration of Imrang sand beach deformation without and with construction of jetty. The specification of the installed jetty, which is able to control sedimentation concentration was decided based on the prediction of the Imrang beach area changes by space and time. As a result, the jetties constructed in the estuary retarded the rate of sand sediment, so that the effect area of sand sedimentation was obviously decreased. In addition, the measured field data indicated that the sediment deposition inside of dikes could be controlled and the right side area of jetties could be preserved without sediment deposition.
\end{abstract}

Keywords: Prevention of coastal topographical change, Distribution of wave height, Shoreline changes

\section{Introduction}

The high intensity of land use for the citizen activities is growing as the estuary of the small river is closer to the central area of Busan City, South Korea (Fig.1). The upstream area of the estuary has been urbanized by developments and lots of sediments have been flowed by floods, which cause geographical changes of the estuary. The study area of this paper is the estuary of Choa-kwang Stream in Busan City of Korea and Imrang Beach is located in the left side of this estuary. Figure 2 . Shows an plane of study area. Sediment influx due to the development of the upstream area affects the sand bar formation in this estuary and contributes to the stability of Imrang Beach. The right side of the

\footnotetext{
${ }^{*}$ Corresponding author. Tel.: +82-51-510-2427, Fax.: +82-51-513-9596 E-mail address: sakpark@pusan.ac.kr Copyright $@$ KSOE 2011.
}

estuary is the natural shoreline with the joint formation of rocks. Before the urbanization of the upstream basin, the sand spit was developed by waves during 6 months of dry season from October to March and eliminated by floods during wet season from May to September. However, geographical features have been unstable because of sediment flux increased by the urbanization in the watershed and the ecosystem has been changed by sediment diffusion in the estuary. Figure 3 shows sand spit's changes after construction of jetties. Figure 4 illustrates deformation of Imrang sand beach. Therefore, the countermeasure is required to control the increased sediment influx in this area. The jetty is proposed as one of countermeasures, which can discharge sediment influx to the relatively deepdepth. The objectives of this study are to examine the sediment diffusion zone and concentration distribution for the three cases, without the jetty, with 
the only south jetty, and with the jetty and to provide basic information to determine the layout of the jetty.
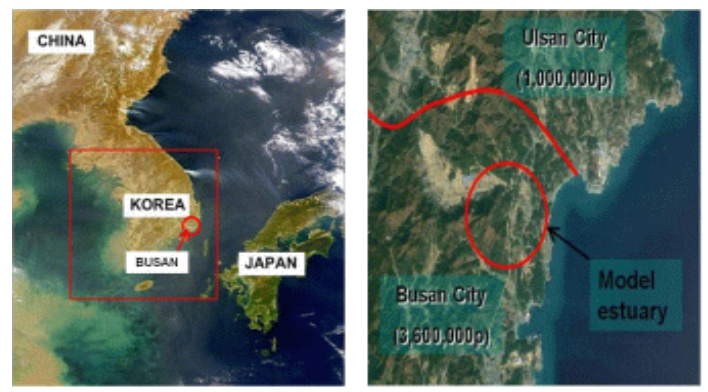

Fig. 1. Location of study area

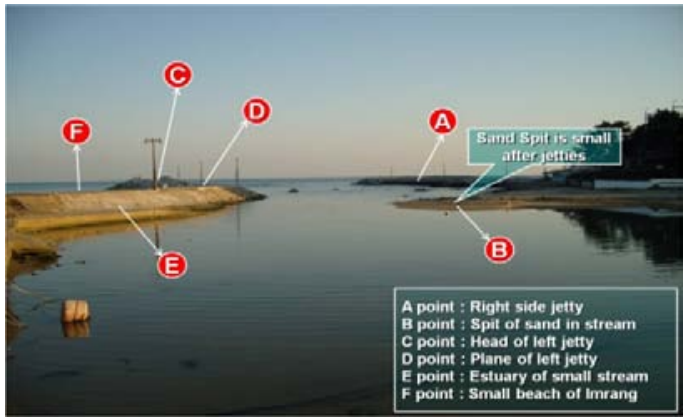

Fig. 2. Plane of small stream Estuary River
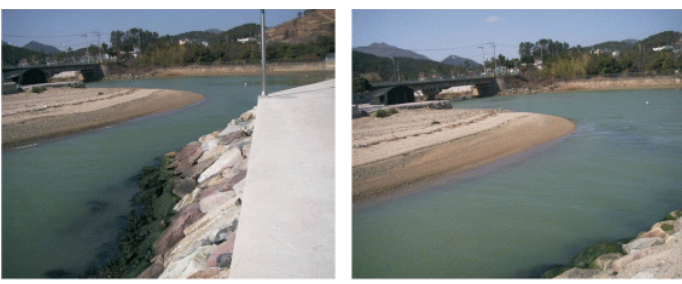

Fig. 3. Spit of sand small stream
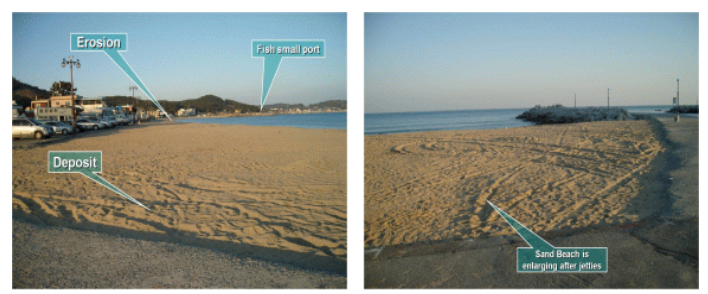

Fig. 4. Deformation of sand beach

\section{Numerical Model}

\subsection{Overview of the model}

Numerical modeling for this study can be divided to two parts: one is calculation of wave height and the other is current. Physical modeling is change of shoreline. Wave and current simulations are to analyze characteristics of wave changes and waveinduced current by installation of the jetty in the estuary of Choa-kwang Stream and numerical modeling of sediment dispersion is to calculate the dispersion range of sediment flux and sediment transported from the upstream channel.

\subsection{Wave and current model}

Energy equilibrium Equation and Hyperbolic and mild slope Equation were used to calculate wave height in the model area, continuity equation and momentum equation were used to calculate current in model. The equations are as following.

$$
\begin{aligned}
& \frac{\partial D}{\partial t}+\nabla \cdot(D \vec{V})-Q=0 \\
& \frac{\partial \vec{Q}}{\partial t}+C^{2} \nabla \eta+f_{D} \vec{Q}=0 \\
& \frac{\partial \eta}{\partial t}+\frac{1}{n} \nabla \cdot(n \vec{Q})=0 \\
& \frac{\partial \bar{\zeta}}{\partial t}+\frac{\partial}{\partial x_{i}}\left[U_{i}(h+\bar{\zeta}]=0\right. \\
& \frac{\partial}{\partial t}\left[(h+\bar{\zeta}) U_{j}+\frac{\partial}{\partial x_{i}}\left[h+\bar{\zeta} U_{i} U_{j}\right)\right]+g(h+\bar{\zeta}) \frac{\partial \bar{\zeta}}{\partial x_{j}} \\
& +\frac{1}{\rho} \frac{\partial s_{i j}}{\partial x_{i}}-\frac{\partial}{\partial x_{i}}\left[K_{i j}(h+\bar{\zeta}) \frac{\partial U_{j}}{\partial x_{i}}\right]+\frac{1}{\rho} \tau_{j}^{B}=0
\end{aligned}
$$

\subsection{Wave and Wave-induced current simulation}

The research area was divided into wide and detailed modeling parts to simulate different conditions of ordinary and surging waves. The approximated highest water level of $100.9 \mathrm{~cm}$ was used for the surging wave condition and the mean sea level of $50.9 \mathrm{~cm}$ was adopted for the ordinary wave condition. Numerical modeling was conducted using depth averaged, unsteady, nonlinear governing equations to analyze the wave-induced current, which causes bed-form changes. 
Table 1. Numerical model of wave and current

\begin{tabular}{|c|c|c|c|c|}
\hline \multirow{2}{*}{$\begin{array}{l}\text { Used } \\
\text { Model }\end{array}$} & \multicolumn{3}{|c|}{ Wave deformation model } & \multirow{2}{*}{$\begin{array}{l}\text { Current } \\
\text { Model }\end{array}$} \\
\hline & & Energy equilibrium Eq. & Hyperbolic and mild slope Eq. & \\
\hline Area & & Deep water Area & Detail domain & Detail domain \\
\hline Exp. & & S(SSW) & \multirow{2}{*}{$1.0 \mathrm{~km} \times 1.9 \mathrm{~km}$} & \multirow{2}{*}{$1.0 \mathrm{~km} \times 1.9 \mathrm{~km}$} \\
\hline Area & & $20 \mathrm{~km} \times 30 \mathrm{~km}$ & & \\
\hline Mesh & & $100 \mathrm{~m}$ & $5 \mathrm{~m}$ & $5 \mathrm{~m}$ \\
\hline Grid & & S(SSW) & & \\
\hline No. & & $200 \times 300$ & $200 \times 380$ & $200 \times 380$ \\
\hline \multirow{6}{*}{$\begin{array}{l}\text { Input } \\
\text { Data }\end{array}$} & \multirow{3}{*}{$\begin{array}{c}\text { Surging } \\
\text { Wave }\end{array}$} & Wave height : $5.3 \mathrm{~m}$ & Wave height : $2.9 \mathrm{~m}$ & \multirow{6}{*}{ Radiation Stress } \\
\hline & & Period : 10.0 sec & Period : 10.0sec & \\
\hline & & Direction : SSW & Direction : S18.0 ${ }^{\circ} \mathrm{E}$ & \\
\hline & \multirow{3}{*}{$\begin{array}{c}\text { Ordinary } \\
\text { Wave }\end{array}$} & Wave height : $2.0 \mathrm{~m}$ & Wave height : $2.0 \mathrm{~m}$ & \\
\hline & & Period : $12.0 \mathrm{sec}$ & Period : 12.0sec & \\
\hline & & Direction : SSW & Direction : $21.5^{\circ} \mathrm{E}$ & \\
\hline
\end{tabular}

The radiation stress based on modeling results of the wave was used for the wave forcing. The horizontal dispersion coefficient was the bed friction coefficient was 0.01 in the model. Table 1 presents the modeling description such as grid, mesh, input data, etc. Figure 5 shows numerical calculation grid.

The numerical simulation result of ordinary waves is described in Figure 6 without jetty. The calculation results show that incident current break in $4.0 \mathrm{~m}$ to $5.0 \mathrm{~m}$ depth and the distribution of wave heights that can transport sands on the beach is from $0.5 \mathrm{~m}$ to $1.5 \mathrm{~m}$. The numerical modeling result of the ordinary wave condition with the jetty is plotted in Figure 7 and Figure 8 with jetty. Wave heights around the jetty are similar to the condition without the jetty however waves on the inside of the dikes are blocked.

\subsection{Littoral current deformation}

The numerical simulation result is described in Figure 7, 8 with jetty, respectively. The littoral current with the direction from the breakwater to the center of the beach and the eddy current near the breakwater were occurred under the condition without jetties. The relatively larger magnitude of littoral and eddy currents and the additional eddy current were formed in the condition with jetties.

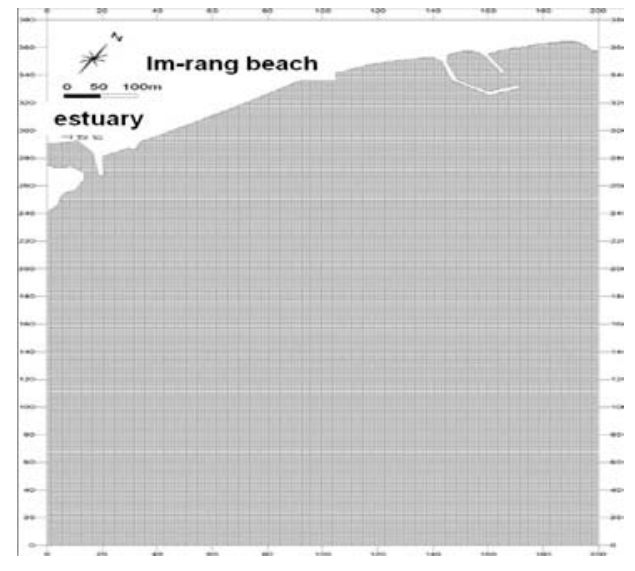

Fig. 5. Sketch of numerical calculation grid

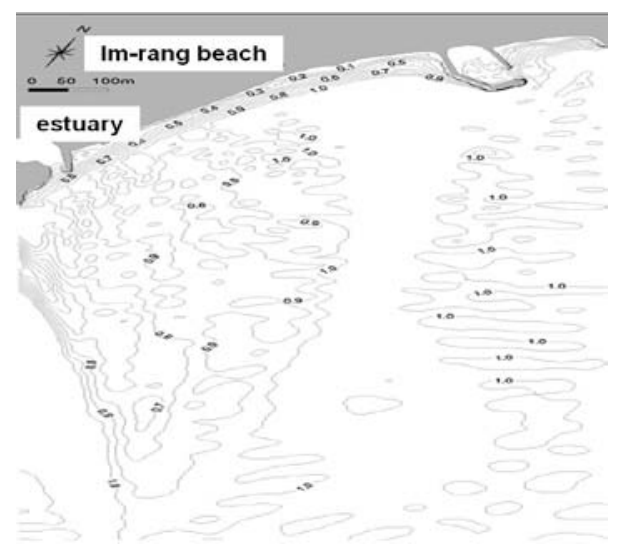

Fig. 6. Distribution of wave height (without jetty)

(Dir=S21.5ํ․ $\mathrm{H}=1.1 \mathrm{~m}, \mathrm{~T}=12.0 \mathrm{sec}$ ) 


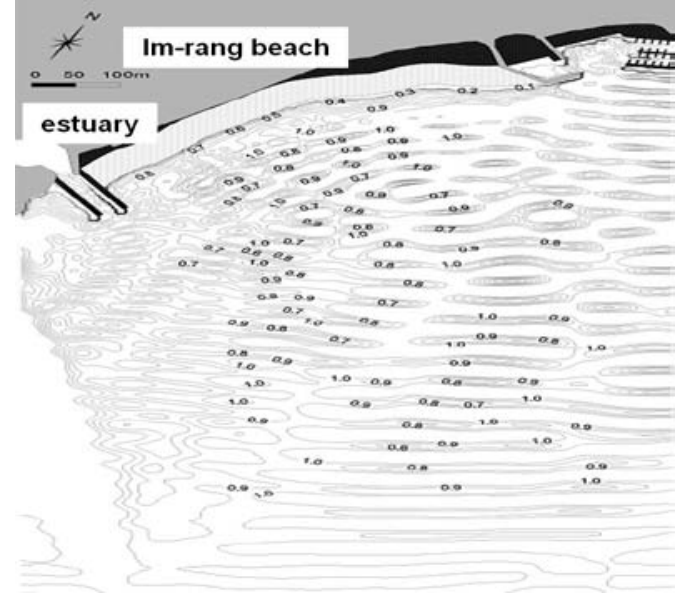

Fig. 7. Distributin of wave height (with jetty)

(Dir=S21.5 ${ }^{\circ}, \mathrm{H}=1.1 \mathrm{~m}, \mathrm{~T}=12.0 \mathrm{sec}$ )

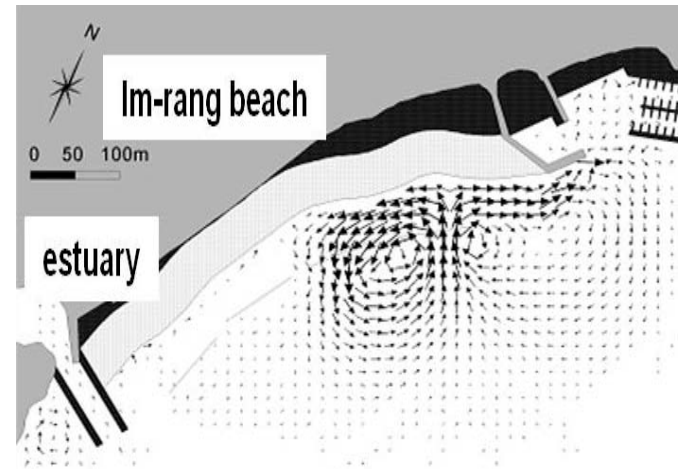

Fig. 8. Wave current vector (with jetty)

(Dir=S18 ${ }^{\circ} \mathrm{E}, \mathrm{H}=2.9 \mathrm{~m}, \mathrm{~T}=10.0 \mathrm{sec}$ )

\section{Physical Model}

\subsection{Experiment condition}

Physical modeling for the rigid bed and mobile bed conditions was conducted to analyze characteristics of wave changes and wave-induced current by installation oft hejetty in the estuary of Choakwang Stream and the effects of jetties on the geographical changes.

Applied wave heights were $5.8 \mathrm{~cm}$ in the model corresponding to $290 \mathrm{~cm}$ in the field for the surging wave and $2.2 \mathrm{~cm}$ in the model corresponding to $110 \mathrm{~cm}$ in the field for the ordinary wave. The pe- riods in the model were $1.4 \mathrm{sec}$ (10 sec in the prototype) and $1.7 \mathrm{sec}$ (12 sec in the prototype) with $\mathrm{S} 35^{\circ} \mathrm{E}$. Table 2 presents the modeling conditions.

Table 2. Condition of Experiments (Field value)

\begin{tabular}{|c|c|c|c|c|c|}
\hline $\begin{array}{l}\text { Exp. } \\
\text { No. }\end{array}$ & Jetty & $\begin{array}{l}\text { Incident } \\
\text { wave }\end{array}$ & $\begin{array}{c}\text { Wave } \\
\text { height }(\mathrm{cm})\end{array}$ & Period(sec) & $\begin{array}{c}\text { Wave } \\
\text { direction }\end{array}$ \\
\hline 1 & Without & $\begin{array}{l}\text { Surging } \\
\text { wave }\end{array}$ & 5.8(290) & $1.4(10.0)$ & $\mathrm{S} 35^{\circ} \mathrm{E}$ \\
\hline 2 & jetty & $\begin{array}{c}\text { Ordinary } \\
\text { wave }\end{array}$ & $2.2(110)$ & $1.7(12.0)$ & $\mathrm{S} 35^{\circ} \mathrm{E}$ \\
\hline 3 & With & $\begin{array}{c}\text { Surging } \\
\text { wave }\end{array}$ & 5.8(290) & $1.4(10.0)$ & $\mathrm{S} 35^{\circ} \mathrm{E}$ \\
\hline 4 & jetty only & $\begin{array}{c}\text { Ordinary } \\
\text { wave }\end{array}$ & $2.2(110)$ & $1.7(12.0)$ & $\mathrm{S} 35^{\circ} \mathrm{E}$ \\
\hline 5 & With & $\begin{array}{l}\text { Surging } \\
\text { wave }\end{array}$ & 5.8(290) & $1.4(10.0)$ & $\mathrm{S} 35^{\circ} \mathrm{E}$ \\
\hline 6 & Bi-jetty & $\begin{array}{c}\text { Ordinary } \\
\text { wave }\end{array}$ & $2.2(110)$ & $1.7(12.0)$ & $\mathrm{S} 35^{\circ} \mathrm{E}$ \\
\hline
\end{tabular}

\subsection{Analysis of experimental results}

\subsubsection{Rigid bed experiment}

The rigid bed experiment was performed to estimate the changes of wave heights due to the installation of jetties. Figure 9 and 10 represent the wave changes before and after the dike construction. For the ordinary wave condition before the dike construction, the waves break in the area with $1.5 \mathrm{~m}$ to $2.5 \mathrm{~m}$ and the waves of $0.9 \mathrm{~m}$ to $1.1 \mathrm{~m}$ height are transported to the beach. For the surging wave condition before the dike construction, the waves break in the area with $4.0 \mathrm{~m}$ to $5.0 \mathrm{~m}$ and the waves of 1.0 $\mathrm{m}$ to $2.2 \mathrm{~m}$ height are transported to the beach. After the dike construction, the waves of $0.1 \mathrm{~m}$ to 0.5 $\mathrm{m}$ height for the ordinary wave are transported to the beach due to the wave interception by dikes and the waves of $0.5 \mathrm{~m}$ to $1.0 \mathrm{~m}$ hit the Imrang Beach side. For the case of the surging wave, the waves with $0.2 \mathrm{~m}$ to $1.5 \mathrm{~m}$ height are distributed in the estuary and the waves heights of $0.6 \mathrm{~m}$ to $1.7 \mathrm{~m}$ height are occurred in the Imrang Beach side. 


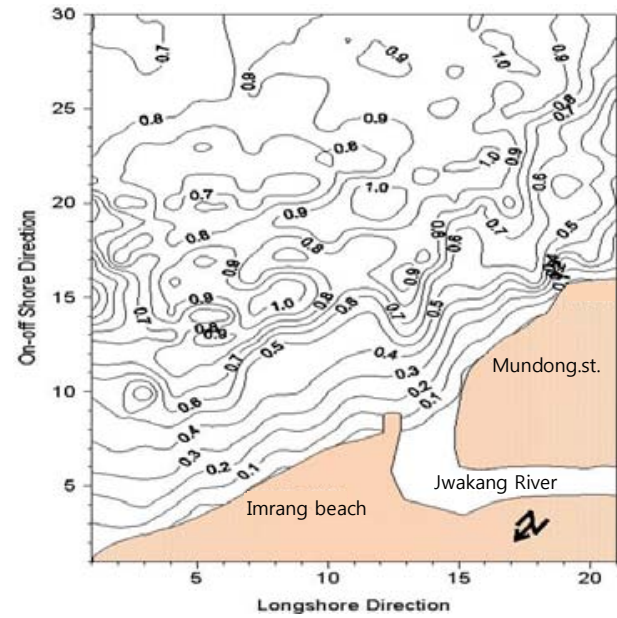

Fig. 9. Wave height distribution for the surging wave (Dir=S35ํ․ $\mathrm{H}=5.8 \mathrm{~m}, \mathrm{~T}=1.4 \mathrm{sec}$, without dikes)

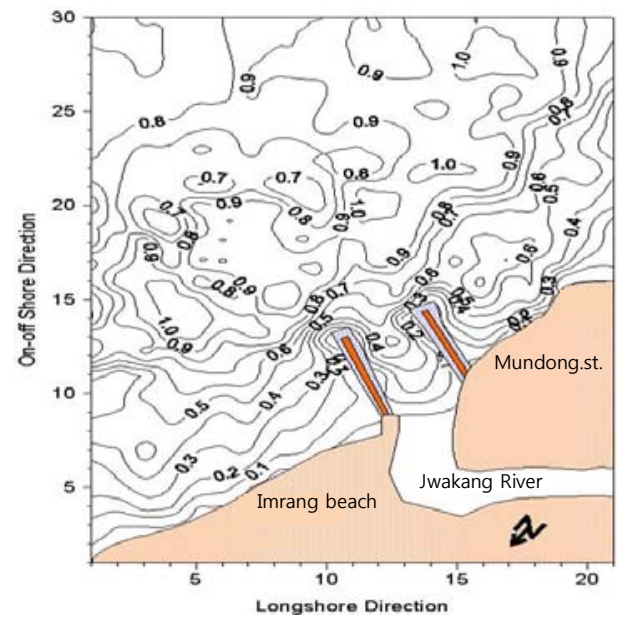

Fig. 10. Wave height distribution for the surging wave (Dir=S35 ${ }^{\circ}$, $\mathrm{H}=5.8 \mathrm{~m}, \mathrm{~T}=1.4 \mathrm{sec}$, with dikes)

\subsubsection{Movable bed experiment}

Figure 11 and 12 show the bed elevation changes after 4 hours of the surging wave with and without dikes. The bed near the estuary was deposited maximum $0.95 \mathrm{~m}$ without dikes; however, the bed changes in the Imrang Beach were $0.2 \mathrm{~m}$ to $0.5 \mathrm{~m}$. For the condition with dikes, the bed changes at the end of dikes had both of the erosion of $0.5 \mathrm{~m}$ and the deposition of $1.3 \mathrm{~m}$ and there was the bed erosion of $0.2 \mathrm{~m}$ to $0.5 \mathrm{~m}$ at the Imrang Beach in the surging wave experiment.

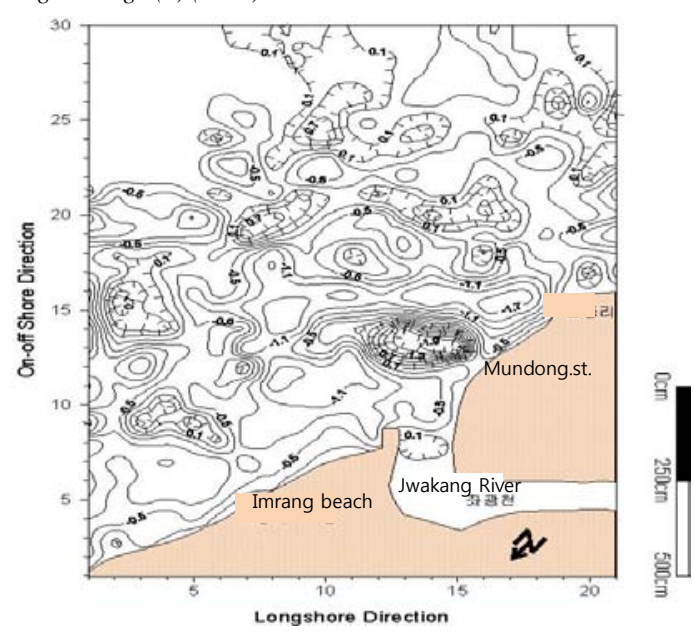

Fig. 11. Bed elevation changes for the surging wave (Dir=S35 ${ }^{\circ} \mathrm{E}, \mathrm{H}=5.8 \mathrm{~m}, \mathrm{~T}=1.4 \mathrm{sec}$, without dikes)

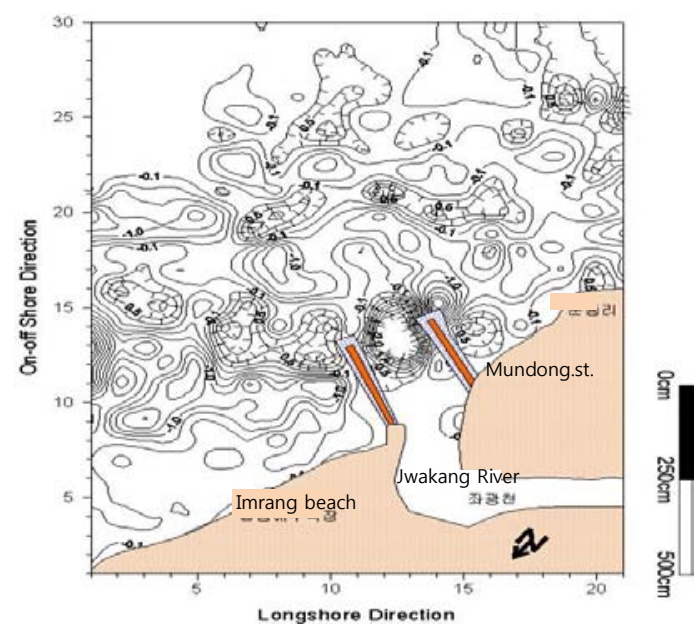

Fig. 12. Bed elevation changes for the surging wave

(Dir=S35 ${ }^{\circ}$, $\mathrm{H}=5.8 \mathrm{~m}, \mathrm{~T}=1.4 \mathrm{sec}$, with dikes)

Figure 13 and 14 show the shoreline changes during 4 hours of the surging wave with and without dikes. The shoreline was moved back about 1.0 $\mathrm{m}$ to $3.0 \mathrm{~m}$ at the estuary of Choa-kwang Stream and maximum $7.0 \mathrm{~m}$ at the left and right sides of jetties when the jetties were not located in the estuary. However, the shoreline was moved back $0.5 \mathrm{~m}$ at the estuary of Choa-kwang Stream and maximum $5.0 \mathrm{~m}$ at the left (Imrang Beach) and right sides of jetties when the jetties were installed in the estuary. Therefore, it is considered that the jetty contributes to the shoreline conservation. 


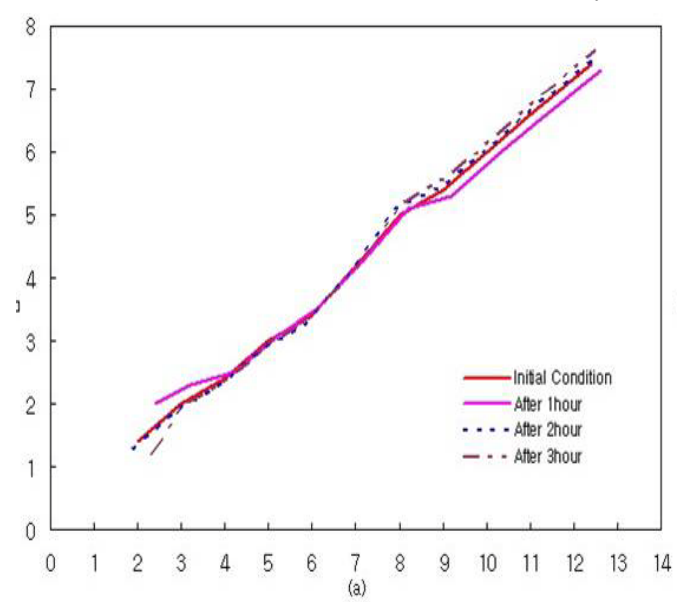

Fig. 13. Shoreline changes for the surging wave (Dir=S35 $, \mathrm{H}=5.8 \mathrm{~m}, \mathrm{~T}=1.4 \mathrm{sec}$, without dikes)

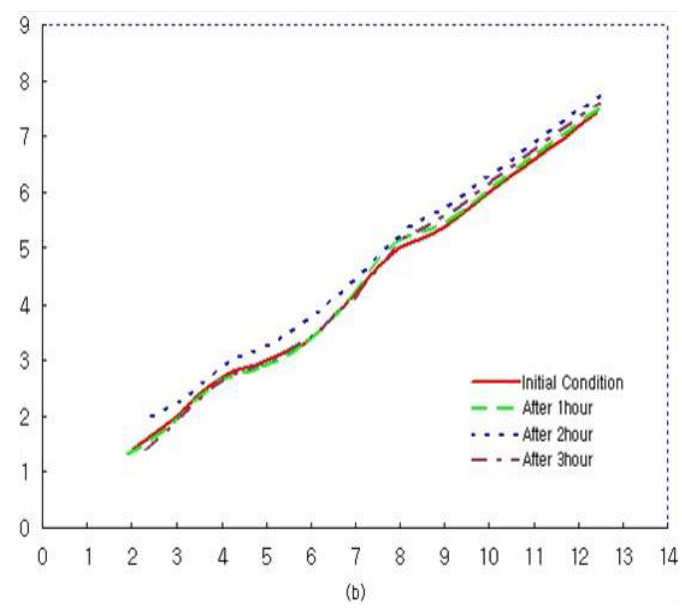

Fig. 14. Shoreline changes for the surging wave (Dir=S35 ${ }^{\circ}$, $\mathrm{H}=5.8 \mathrm{~m}, \mathrm{~T}=1.4 \mathrm{sec}$, with dikes)

\section{Conclusions}

The diffusion zone of sediment concentration in the estuary of Choa-kwang Stream and Imrang Beach with and without jetties was analyzed using numerical and physical models. Main conclusions for this study are summarized as followings.

First, the construction of jetties at the estuary of Choa-kwang Stream is very helpful to control the waves and currents.

Second, the deposition of $2.6 \mathrm{~cm}$ in the physical model (1.3 $\mathrm{m}$ in the prototype) was occurred at the inside of dikes, which was similar to the field ob- servation. Therefore, it is concluded that the regular dredging operation is necessary to eliminate the deposited sediments.

Third, the shoreline changes without jetties were more active than the condition with jetties because of the effect of wave energy reduction. It is concluded that the installation of jetties is helpful to conserve the shoreline and to discharge sediments from the river.

Forth, the jetties retard the decrease rate of sediment concentration however decrease the dispersion zone of sediment concentration.

\section{Acknowledgements}

The Study has been supported by "The Fund of Research Pusan National University " and also by "The principal R\&D Program of KOWACO"

\section{References}

[1] Kang, J.B. "Hydraulics", Gumiseokwan, pp 657-714.

[2] Korea Maritime and Port Administration. "The design criteria of harbor structures", (1993) pp 191-192.

[3] Korea Maritime and Port Administration. "Report of estimation of design wave height for the Korean harbors", (1998) pp 71-78.

[4] Oh, J.W. "The study of bed form changes in short period around jetties, Master thesis", Pusan National University, (1993) pp 22-27.

[5] Park S.K., Kang K.U., Kim S.M. "A study on the beach stability at the backward of trench by 3-dimensional hydraulic experiment", Vol 21, No. 6-B, KSCE, (2001) pp 655 666

[6] US Army Corps of Engineers (1997). "HECRAS River Analysis System", 1-1 1-8.

[7] Park S.K., Choi B.S "A Study of Waves in the Estuary of Nakdong River", J of KSCE, Vol.16, II-No.4 (1996) pp384-386.

[8] S.K. Park, B.D. Kim, S.I. Jeong, "An Experimental Basic Study of Water Purification Function due to Spit in Small Estuary", J. of KSOE, Vol. 21, No.3, (2007) pp13-14.

[9] I.C. Kim and I.K. Ahn "Measurement and Numerical Model for Wave Interation on Impermeable Steep Slop", J. of KSOE, Vol.22, No.5, (2008) pp45-46. 
[10]S.K Park, W.S. Kim, J.S. Lee, S.H Kim "The Stability Riprap on Scattered Submerged Breakwater due to Physical Model", J. of KSOE, Vol. 24, No.1, (2010) pp110-113.

[11]J. Un, Julien P.Y., Park S.K., Kim B.D. "Numerical Modeling for Sedimentation Characteristics of the Lower Nakong River and Sediment Dredging Effects at the Nakdong River
Estuary Barrage", J of KSCE, Vol. 28, No.4B, (2011) pp409-410.

[12]Park S.K., Park H.S., Yoon J.S., Lee S.H. "A Study on Controlling Efflux Sediment Diffusion by Jetty Construction at Small Estuary", J. of KSCE, Vol.29, No.5B, (2009) pp488-489. 